\title{
Multi-year water and surface energy budget of a high-latitude polythermal glacier: evidence for overwinter water storage in a dynamic subglacial reservoir
}

\author{
Andy HODSON, ${ }^{1}$ Jack KOHLER, ${ }^{2}$ Moana BRINKHAUS, ${ }^{1}$ Peter WYNN ${ }^{3}$ \\ ${ }^{1}$ Geography Department, University of Sheffield, Sheffield S10 2TN, UK \\ E-mail: a.j.hodson@sheffield.ac.uk \\ ${ }^{2}$ Norwegian Polar Institute, Polar Environmental Centre, NO-9296 Tromsø, Norway
}

${ }^{3}$ School of Geography, Earth and Environmental Sciences, University of Birmingham, Edgbaston, Birmingham B15 2 TT, UK

\begin{abstract}
This paper examines the water budget and surface energy balance of a Svalbard glacier (midre Lovénbreen) over a 6 year period (1997-2002). Fresh-water yields are found to lie between 1.1 and $1.5 \mathrm{~m} \mathrm{a}^{-1}$ and reflect variable amounts of glacier ice ablation $\left(0.27 \pm 0.15 \mathrm{~m} \mathrm{a}^{-1}\right)$ and more consistent amounts of snowmelt and summer precipitation $(0.40 \pm 0.10$ and $0.49 \pm 0.12 \mathrm{~m}$ respectively). Between $24 \%$ and $36 \%$ of the annual runoff is thought to pass through a subglacial drainage system. Although the site is heavily influenced by stable maritime air masses during the summer, surface melting is achieved largely by net shortwave radiation fluxes $(74-100 \%$ of ablation). Water budget analysis shows that the annual runoff yields may be strongly influenced by water storage within the glacial system. Storage can occur over the winter period and force the early development of the subglacial drainage system during the following summer. Thus annual water fluxes from this glacier cannot be estimated from glacial massbalance data alone and there is a need to assess the implications of overwinter storage for our understanding of glacial dynamics, annual fluvial process rates and mixing processes in Svalbard's fjords.
\end{abstract}

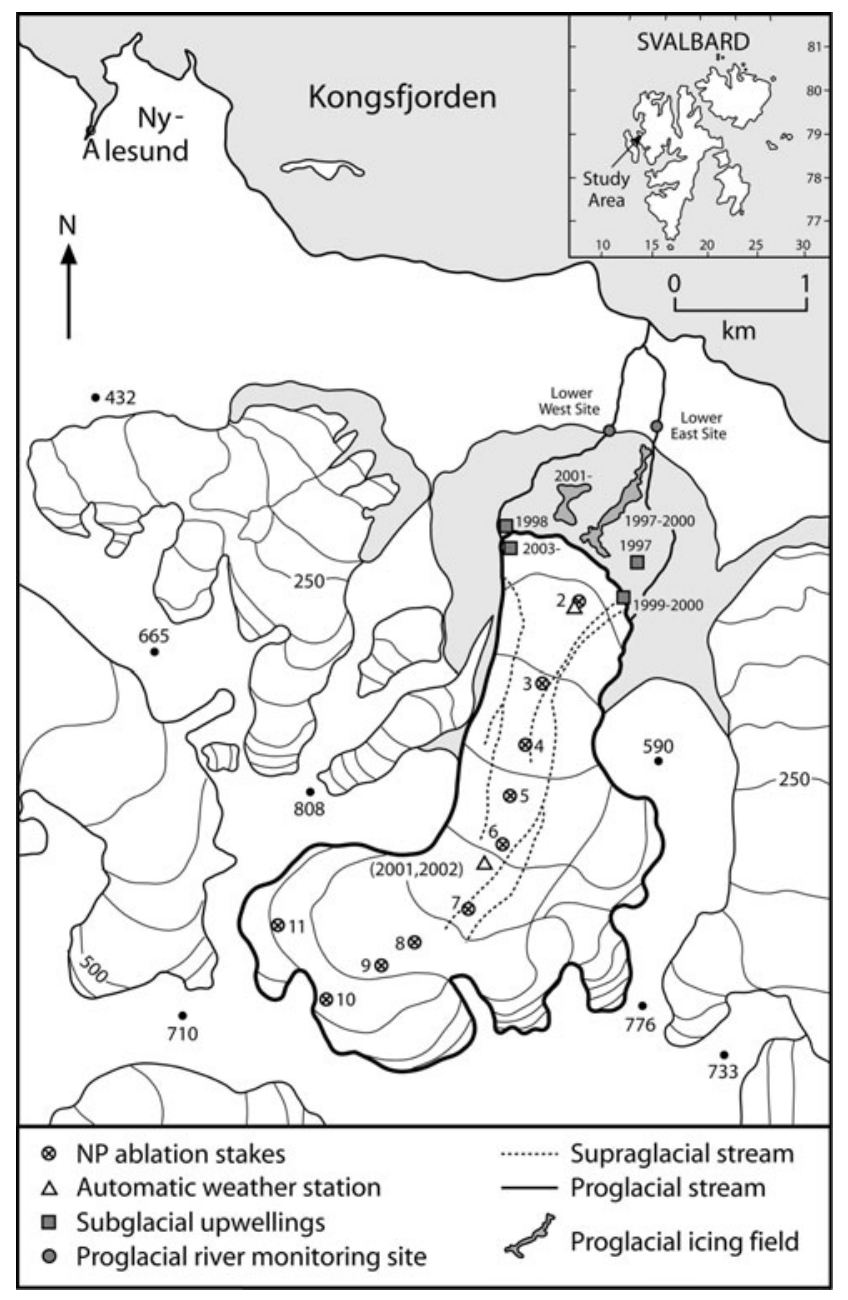

Fig. 1. The midre Lovénbreen basin, its major features and the location of the measurement sites.

\section{INTRODUCTION}

Svalbard's location at the northernmost loop of the Gulf Stream means it is well placed for examining the impacts of heat advection from mid- to high latitudes on the cryosphere. In general, Svalbard's climate is influenced by sea surface temperatures in the Norwegian Sea, by sea-ice extent in the Barents Sea and Fram Strait and by the tracks of Arctic weather systems that are responsible for incursions of cold Arctic air (Førland and Hanssen-Bauer, 2003). Interactions between these factors mean that Svalbard's winter temperatures are highly variable from year to year.

Two Svalbard glaciers, midre Lovénbreen and austre Broggerbreen, have the longest Arctic mass-balance records (Hagen and others, 2003; Kohler and others, unpublished data). However, detailed surface energy-balance studies on Svalbard glaciers are rare, limiting our ability to examine how changes in energy exchange between the atmosphere and snow/ice surfaces in summer may impact upon the generation of fresh-water runoff for mixing in downstream aquatic and marine ecosystems (Hop and others, 2002). Thus, this paper describes the hydrometeorological processes governing meltwater generation and runoff between 1997 and 2002 at the midre Lovénbreen catchment $\left(78^{\circ} 50^{\prime} \mathrm{N}, 12^{\circ} \mathrm{E}\right)$. Specifically, we examine summer surface energy balances and annual water budgets, enabling us to calculate interannual variations in water storage within the glacier (cf. Jansson and others, 2003).

\section{DATA AND METHODS \\ Field site}

Midre Lovénbreen is a $5.4 \mathrm{~km}^{2}$ polythermal glacier that occupies a $10.8 \mathrm{~km}^{2}$ basin (Fig. 1). The glacier is up to $180 \mathrm{~m}$ thick, and about two-thirds of its bed is at the pressuremelting point (Rippin and others, 2003). The glacier and its 
neighbour, austre Brøggerbreen, have mass-balance records extending back to the late 1960s. There have been a few previous studies of midre Lovénbreen's hydrology; estimates of annual runoff, chemical denudation and nutrient budgets were presented by Hodson and others (2000, 2005), and aspects of the internal glacier drainage system have been inferred using ground-penetrating radar and other geophysical methods by Kulessa and Murray (2003) and Rippin and others (2003).

\section{Mass balance}

The long-term mass-balance record shows that elevation exerts a strong control over winter accumulation $b_{\mathrm{w}}$ explaining $99.7 \%$ of the variance in the average accumulation of the glacier's $50 \mathrm{~m}$ elevation zones (Kohler, unpublished data). These zones have an accumulation range of $0.2-0.9 \mathrm{~m}$ w.e. and produce an average precipitation gradient for the basin of $0.13 \mathrm{mw}$.e. $(100 \mathrm{~m})^{-1}$ during the study period (1997-2002). Typically, summer melting on the glacier nearly always exceeds these winter accumulation rates, so the glacier has had an almost consistently negative net mass balance $\left(b_{n}\right)$ since records began in 1967, with only four years in which $b_{\mathrm{n}}$ was positive. The long-term average $b_{\mathrm{n}}$ since 1967 ( $-0.36 \mathrm{~m}$ w.e.) is also close to that for our study period (-0.38 m w.e.).

\section{Discharge}

Summer runoff is conveyed to Kongsfjord via two proglacial streams draining the lateral margins of the glacier. Subglacial drainage also occurs in the summer, and subglacially routed water typically emerges in the first half of July as either single or multiple upwellings in the glacier forefield. Changes in the location of the upwellings reflect changes in subglacial drainage system structure (Rippin and others, 2003). Proglacial icings form every winter, indicating that subglacially routed water emerges from the glacier throughout the year. Interestingly, these icing features may also form in different locations from year to year, and they are never observed in the same location as the subglacial upwellings.

Since July 1997, standard methods have been employed to measure runoff from the glacier and its $\sim 1.54 \mathrm{~km}^{2}$ forefield (see Fig. 1 and Hodson and others, 2005 for further details). These runoff data are incomplete, so the series have been filled using simple regression models and data from a permanent Norwegian Water and Energy Administration (NVE) gauging station, $\sim 4 \mathrm{~km}$ west of the study site draining the Bayelva catchment (see Hagen and others, 2003). Two models were necessary to account for missing data: one for before day of year (DOY) 190 (early season) and one for after DOY 205. All missing data $(\sim 50 \%$ of the total runoff between 1997 and 2002) were represented by these intervals. The models took the form:

$$
\begin{aligned}
Q_{\mathrm{ML}}^{\text {early }} & =0.179( \pm 0.013) Q_{\mathrm{B}}^{\text {early }}+650( \pm 6400) \\
Q_{\mathrm{ML}}^{\text {late }} & =0.245( \pm 0.016) Q_{\mathrm{B}}^{\text {late }}+28700( \pm 5300) .
\end{aligned}
$$

$Q_{\mathrm{ML}}$ and $Q_{\mathrm{B}}$ represent daily runoff volumes for midre Lovénbreen and the Bayelva catchment respectively, and the superscripts 'early' and 'late' represent before DOY 190 and after DOY 205 respectively. The errors of the model parameters are shown in parentheses. The number of observations for Equations (1) and (2) was 30 in each case, whilst the coefficients of determination $\left(r^{2}\right)$ were $0.88 \%$ and $0.89 \%$ and the standard errors of the model were 13500 and
$15800 \mathrm{~m}^{3} \mathrm{~d}^{-1}$ respectively. Three years of data were used in each model, and their slopes were both highly significant at $p<6 \times 10^{-14}$. Model predictions were in close agreement with a coupled temperature index and runoff model developed by Brinkhaus (2003). The larger parameter values of Equation (2) were due to the release of subglacial runoff from beneath midre Lovénbreen during the latter half of summer.

\section{Meteorological data and water balance}

Hourly meteorological data were collected from a single site on the glacier surface, at $\sim 75$ ma.s.l. between 1997 and 2000, and at $\sim 310 \mathrm{~m}$ a.s.l. for 2001 and 2002. We report all data standardized to the original $75 \mathrm{~m}$ altitude using a fixed lapse rate of $0.635^{\circ} \mathrm{C}(100 \mathrm{~m})^{-1}$ for the 2001 and 2002 data. Hourly wind-direction samples and hourly averages of wind speed, air temperature, relative humidity, incident radiation and net radiation were logged using a CR10x data logger. In addition, hourly total ablation was measured using an acoustic ranging sensor. Turbulent (latent- and sensible-heat) and radiative (short- and longwave) energy-balance components during melting were estimated for $75 \mathrm{~m}$ altitude using Brock and Arnold's (2000) surface energy-balance model. Albedo values were calculated for snow (0.50-0.70) and ice (0.22-0.38) using net radiation measurements after solving the longwave radiation balance for incoming radiation using standard empirical relationships based upon cloud cover (see Brinkhaus, 2003). Surface roughness was parameterized using mean observations collected by N. Arnold (unpublished data). These were $2.53 \mathrm{~mm}$ for glacier ice and $0.25 \mathrm{~mm}$ for snow.

Gaps were filled in the air-temperature series using data collected by the Norwegian Meteorological Institute in NyAllesund ( $\sim 3 \mathrm{~km}$ west of the glacier) and the regression model:

$$
T_{\mathrm{ML}}=0.94( \pm 0.0079) T_{\mathrm{N} \AA}-0.25( \pm 0.061) .
$$

$T_{\mathrm{ML}}$ and $T_{\mathrm{NA}}$ denote hourly air temperatures at midre Lovénbreen and $\mathrm{Ny}$-Ålesund respectively, whilst values in parentheses represent the standard errors of the parameters. For this regression, 18000 observations were used, $r^{2}$ was 0.95 and the standard error of the model was $1.57^{\circ} \mathrm{C}$. The slope was significant at $p<1 \times 10^{-6}$, the intercept at $p=3 \times 10^{-5}$. The range of values that supported this relationship extended from $-25^{\circ} \mathrm{C}$ to $13^{\circ} \mathrm{C}$.

The water budget of the glacier was estimated from:

$$
P_{\mathrm{abl}}+P_{\mathrm{acc}}+b_{\mathrm{n}}+C=Q+E \pm \Delta S .
$$

All units are in $\mathrm{ma}^{-1}, P_{\mathrm{abl}}$ is precipitation (usually rain) that falls in the ablation season (summer) and does not refreeze in the basin, $P_{\text {acc }}$ is precipitation during the accumulation season (winter), $b_{n}$ is the net balance of the glacier (representing either firn accumulation (positive values) or glacier ice ablation (negative values) and normalized for the entire catchment area), $Q$ is runoff, $C$ is condensation, $E$ is evaporation and $\Delta S$ is water storage. Winter runoff is accounted for because the gauging stations were installed downstream of the proglacial icing. Note that in other studies of glacier water balance in Svalbard (e.g. Hagen and others, 2003), the storage term is neglected under the assumption that groundwater storage is minimal due to permafrost conditions. We wish to test this assumption, so Equation (4) was solved for $\Delta S$ using our runoff observations, massbalance data and estimates of precipitation, condensation 

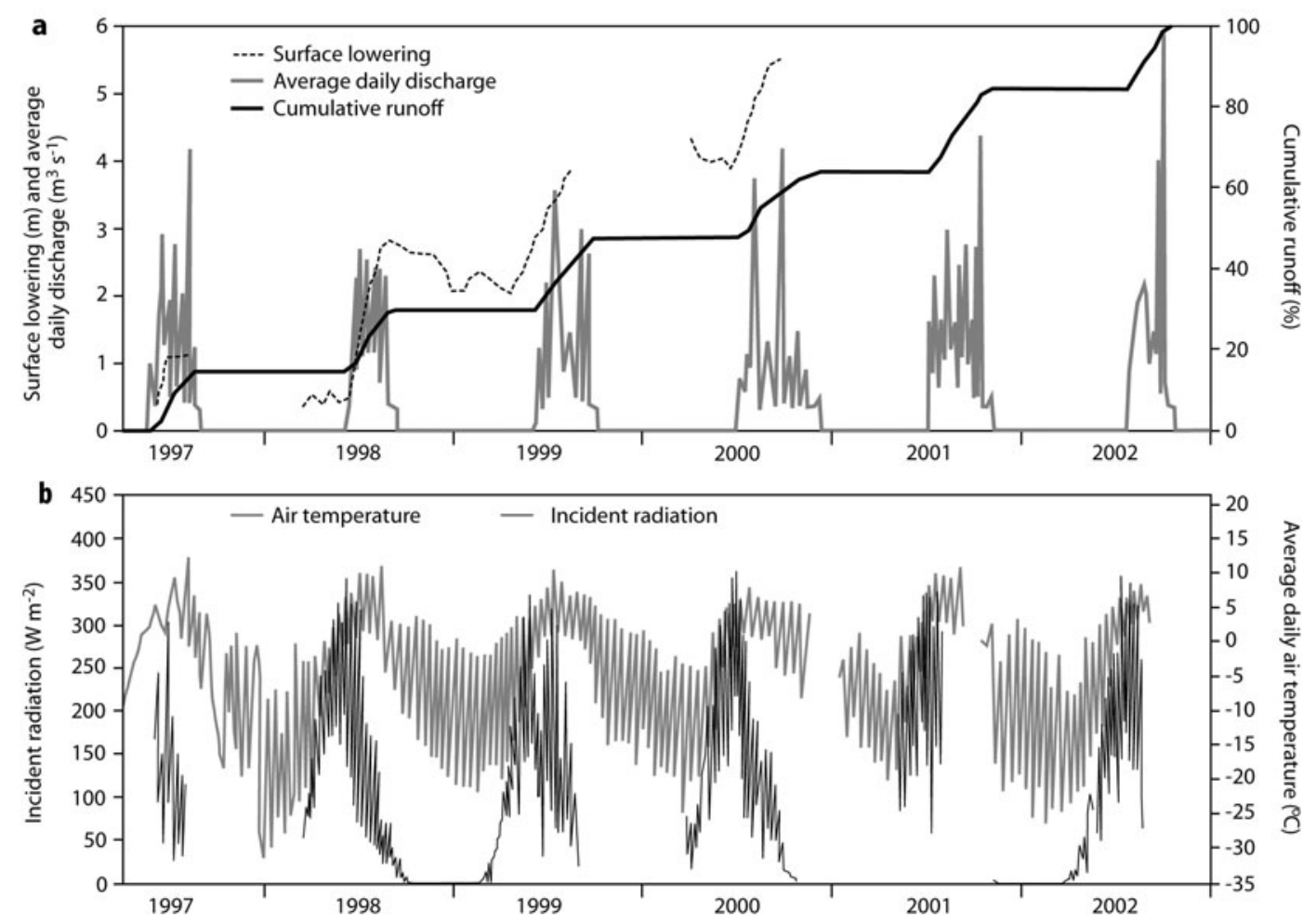

Fig. 2. (a) Daily values of surface lowering at the automatic weather station, average runoff during summer and cumulative runoff. (b) Average air temperature and incident radiation at the automatic weather station.

and evaporation during summer. Summer precipitation was estimated directly from the Norwegian Institute for Air Research (NILU) weekly sampling programme in $\mathrm{Ny}$ Ålesund using empirical transfer functions and a precipitation gradient $\left(1 \mathrm{~mm} \mathrm{~m}^{-1}\right)$ described in Hodson and others (2005). Evaporation was assumed to be $0.08 \mathrm{~m} \mathrm{a}^{-1}$ for the glacier forefield (Killingtveit and others, 2003) and negligible elsewhere. Condensation was assumed to be significant over the glacier only and thus calculated using the energy-balance model. Error calculations for this solution of the waterbalance equation followed Hodson and others (2005). Briefly, the main error terms were defined by the standard error of the discharge rating curve for $Q$ (variable, but between 0.11 and $0.15 \mathrm{~m} \mathrm{a}^{-1}$ when errors with Equations (1) and (2) were also considered) and by error estimates for mass-balance terms following Jansson (1999) $\left(0.1 \mathrm{~m} \mathrm{a}^{-1}\right.$ for $b_{\mathrm{n}}, 0.071 \mathrm{~m} \mathrm{a}^{-1}$ for $\left.P_{\text {acc }}\right)$. Since no data were available for the significant uncertainty that was likely to have been associated with $P_{\mathrm{abl}}$, we assumed this was equivalent to the $P_{\mathrm{acc}}$ error. Errors in $C$ and $E$ were not considered since these terms were found to be insignificant.

\section{METEOROLOGICAL CONDITIONS AND SURFACE ENERGY BALANCE}

Figure 2 shows daily incident radiation and air temperature throughout the study, whilst Table 1 shows details of the meteorological conditions during the summer months. Mean daily air-temperature and relative humidity values peak during July, indicating the importance of humid maritime air advection during the summer. Variability in air temperature is inversely correlated with mean values because dynamic interactions between cold northeasterly and warmer southwesterly air masses are typically restricted during the summer periods (e.g. Hodson and others, 1998). Precipitation is high during all summers and even exceeds winter accumulation in 2000. There is typically a steady increase in precipitation throughout the ablation season. In contrast,

Table 1. Average daily meteorological conditions and total monthly precipitation for the interval 1997-2002 at the weather station (76 m) during summer. Also shown are 1 standard deviation and the number of days with available data (where relevant) in parentheses

\begin{tabular}{|c|c|c|c|c|c|}
\hline & May & June & July & August & September \\
\hline Precipitation (mm month ${ }^{-1}$ ) & $7.16 \pm 6.59$ & $11.7 \pm 8.22$ & $26.4 \pm 21.5$ & $34.2 \pm 34.4$ & $51.2 \pm 43.2$ \\
\hline Insolation $\left(\mathrm{W} \mathrm{m}^{-2}\right)$ & $203 \pm 52.3(150)$ & $231 \pm 70.3(150)$ & $167 \pm 75.4(142)$ & $91.9 \pm 42.8(114)$ & $32.9 \pm 19.2(60)$ \\
\hline Wind velocity $\left(\mathrm{m} \mathrm{s}^{-1}\right)$ & $2.27 \pm 1.50(140)$ & $2.15 \pm 1.22(150)$ & $2.32 \pm 0.811(142)$ & $2.10 \pm 0.793(114)$ & $2.32 \pm 1.01(60)$ \\
\hline Positive degree-day $\left({ }^{\circ} \mathrm{Cd}^{-1}\right)$ & $13.0 \pm 27.0(150)$ & $61.6 \pm 49.7(180)$ & $110 \pm 45.9(177)$ & $88.8 \pm 51.8(136)$ & $35.1 \pm 44.7(150)$ \\
\hline Mean runoff $\left(\mathrm{m}^{3} \mathrm{~s}^{-1}\right)$ & None & $0.395 \pm 0.52(180)$ & $1.60 \pm 0.712(183)$ & $1.26 \pm 0.711(183)$ & $0.69 \pm 0.73(150)$ \\
\hline
\end{tabular}


Table 2. Mean daily heat fluxes (as $\mathrm{mm} \mathrm{d}^{-1}$ w.e.) during melting conditions, and the percentage of energy supplied for melt by fluxes of sensible heat (SHF), latent heat (LHF) shortwave radiation (SWR) and longwave radiation (LWR)

\begin{tabular}{|c|c|c|c|c|c|}
\hline Month & SHF & LHF & SWR & LWR & Total flux \\
\hline June & $1.46 \pm 5.69(6.6 \%)$ & $-0.168 \pm 4.22(0 \%)$ & $20.8 \pm 11.8(93.4 \%)$ & $-12.1 \pm 5.71(0 \%)$ & $10.0 \pm 16.1$ \\
\hline July & $3.74 \pm 5.21(14.7 \%)$ & $2.42 \pm 3.17(7.8 \%)$ & $24.1 \pm 18.6(77.6 \%)$ & $-8.71 \pm 4.25(0 \%)$ & $22.3 \pm 20.3$ \\
\hline August & $3.86 \pm 4.73(15.6 \%)$ & $1.87 \pm 2.74(8.1 \%)$ & $17.5 \pm 15.4(76.2 \%)$ & $-7.61 \pm 4.56(0 \%)$ & $15.3 \pm 16.2$ \\
\hline September & $-1.06 \pm 4.10(0 \%)$ & $-2.11 \pm 3.89(0 \%)$ & $9.10 \pm 25.0(100 \%)$ & $-11.6 \pm 5.21(0 \%)$ & $-5.64 \pm 26.2$ \\
\hline All data & $13.4 \%$ & $6.4 \%$ & $80.2 \%$ & $0 \%$ & \\
\hline
\end{tabular}

wind velocity was the most stable series throughout the observation period.

Table 2 shows that the energy balance during the ablation seasons over the lower parts of the glacier was dominated by the net shortwave radiation flux, as is common on many glaciers (e.g. Willis and others, 2002). Thus, net shortwave radiation represented, on average, $76-100 \%$ of the total energy used to melt snow and ice, and was most dominant late in the ablation period when turbulent heat fluxes were smaller.

\section{ANNUAL WATER BALANCES AND SUBGLACIAL DRAINAGE}

Table 3 shows the water-balance terms for each ablation season. Summer runoff yields were $1.1-1.5 \mathrm{~m} \mathrm{a}^{-1}$, reflecting significant contributions from summer precipitation $(0.34$ $0.69 \mathrm{~m})$ and ablation $(0.59-1.13 \mathrm{~m})$. Surprisingly, there are years with significant residual water-storage terms (1997 and 2002 both show water retention within the catchment) that exceed our conservative error estimates. Water storage appears to have declined throughout the observation period and then risen sharply during 2002. A possible explanation of the storage phenomena is therefore sought below.

Each summer, the emergence of subglacial drainage in the glacier forefield has a notable effect upon the chemistry and turbidity of the proglacial streams (Hodson and others, 2005; Rippin and others, 2005). Detailed hydrochemical datasets are available for all principal streams and subglacial upwellings during the study period (sampled on a daily or 2 day basis), so a mixing model using dissolved $\mathrm{Si}$ as a basis for flow separation was used to estimate the quantity of runoff emerging via delayed subglacial flowpaths and faster supraglacial/ice-marginal routes (see Rippin and others, 2005 for further details).
Table 3 shows that the proportion of summer runoff routed through the subglacial drainage network was $24-36 \%$ and showed a significant negative correlation with both the glacier's net balance $\left(r^{2}=0.56\right)$ and summer precipitation $\left(r^{2}=0.79\right)$. Thus, high-runoff years are associated largely with more supraglacial and ice-marginal runoff, and proportionately less subglacial runoff. Table 3 also shows the cumulative sum of positive degree-days recorded at the weather station prior to the onset of subglacial runoff from the glacier. The data indicate a possible trend in the amount of energy required to establish subglacial runoff from the glacier each year, which we contend is related to conditions at the glacier bed rather than at the surface. This is because the cumulative positive degree-day sum prior to the onset of subglacial runoff increased significantly $(p=0.002)$ throughout the study period but was not significantly correlated with winter snow accumulation or average spring/early-summer air temperatures (a proxy for snowpack temperatures in the early melt period). Thus, a changing glacial drainage system and/or a change in the level of overwinter water storage within the existing system are required to explain the relationship between melting and the onset of subglacial runoff. Further, there is a significant negative correlation between term $\Delta S$ of the water balance in year $x$ and the degree-day sum in year $x+1\left(r^{2}=0.79\right)$. This suggests that lower spring/early-summer surface energy inputs (and therefore meltwater inputs) are required to initiate subglacial runoff from the glacier when the volume of water stored over the winter period is relatively high. Such a relationship might indicate that initiation of subglacial drainage from the glacier is dependent upon the development of high water pressures within the glacier, and that such water pressures are more readily achieved when there is a large degree of water storage remaining within the system from the previous ablation season. This hypothesis is

Table 3. Water budget estimates, including winter accumulation $\left(P_{\text {acc }}\right)$, summer precipitation $\left(P_{\text {abl }}\right)$, condensation $(C)$, evaporation $(E)$, the net balance of the glacier $\left(b_{\mathrm{n}}\right)$, runoff $(Q)$ and storage $(S)$. All terms are expressed as $\mathrm{ma}^{-1}$ and normalized for total catchment area. \%Sub denotes the proportion of bulk runoff emerging from subglacial springs, and PDD the sum of positive degree-days in ${ }^{\circ} \mathrm{C}{ }^{-1}$ prior to the onset of subglacial runoff. Error estimates for $\Delta S$ are also included

\begin{tabular}{|c|c|c|c|c|c|c|c|c|c|}
\hline Year & $P_{\mathrm{acc}}$ & $P_{\mathrm{abl}}$ & $C$ & $E$ & $b_{\mathrm{n}}$ & $Q$ & $\Delta S$ & $\%$ Sub & PDD \\
\hline 1997 & 0.533 & 0.482 & 0.0170 & 0.012 & 0.327 & 1.105 & $0.24 \pm 0.19$ & 30.1 & 1990 \\
\hline 1998 & 0.513 & 0.338 & 0.0172 & 0.012 & 0.424 & 1.140 & $0.14 \pm 0.21$ & 35.7 & 2141 \\
\hline 1999 & 0.537 & 0.457 & 0.0167 & 0.012 & 0.254 & 1.330 & $-0.08 \pm 0.22$ & 36.2 & 2910 \\
\hline 2000 & 0.495 & 0.694 & 0.0173 & 0.012 & 0.013 & 1.218 & $-0.01 \pm 0.21$ & 24.0 & 2940 \\
\hline 2001 & 0.610 & 0.541 & 0.0170 & 0.012 & 0.205 & 1.527 & $-0.16 \pm 0.23$ & 27.9 & 2950 \\
\hline
\end{tabular}


commensurate with geochemical observations of early subglacial water, which indicate prolonged storage (weeks to months) within an anoxic, geochemically reactive sedimentary environment (see Hodson and others, 2005). Such an environment is most likely to exist at the bed of the glacier rather than elsewhere in the catchment.

\section{DISCUSSION AND CONCLUSIONS}

Six years of meteorological and hydrological observations from midre Lovénbreen show that surface melting is achieved largely by a combination of net shortwave radiation and sensible-heat transfer in the glacier surface in the lower ablation area. These heat fluxes accounted for $80 \%$ and $13 \%$, respectively, of all melting in the lower ablation area between 1997 and 2002. Latent-heat transfer, the next most important heat flux, accounted for only $6 \%$. The corresponding meltwater yields were high, lying between 1.1 and $1.5 \mathrm{~m} \mathrm{a}^{-1}$, which was mostly snowmelt and summer precipitation, since glacier ice ablation only accounted for 0.013-0.42 $\mathrm{m} \mathrm{a}^{-1}$.

The relationship between energy fluxes at the glacier surface and annual runoff is not simple and indicates that large volumes of water are stored within the glacier and that the volume of water stored varies from year to year (accounting for up to $0.47 \pm 0.21 \mathrm{~m} \mathrm{a}^{-1}$ ). High levels of overwinter water storage also appear to influence the development of the drainage system beneath the glacier during the early summer. Thus, summers with lower than expected runoff yields precede summers in which less melt is required to open the subglacial drainage system. A simple explanation might be that high water pressures are required to initiate subglacial runoff and that these are best achieved when early-season subglacial water pressures are already high due to internal water storage. This hypothesis is supported by geochemical observations because the first fractions of subglacial drainage to emerge each year have redox and major-ion chemistries that are diagnostic of prolonged contact with geochemically reactive sediments in an anoxic environment. Thus, although runoff may be expressed as a simple function of melt in glacier basins without extensive subglacial drainage (e.g. Hagen and others, 2003), we argue that this may not be the case in the majority of Svalbard glaciers where extensive parts of the glacier bed are at the pressure-melting point and able to support a subglacial drainage system.

\section{ACKNOWLEDGEMENTS}

Hodson acknowledges UK Natural Environment Research Council grant GR8/04339, the Nuffield Foundation's Newly
Appointed Lecturers Scheme, The Royal Society and the University of Sheffield. P. Jansson, R. Braithwaite and I. Willis are thanked for comments on the manuscript.

\section{REFERENCES}

Brinkhaus, M. 2003. Modelling melt and runoff on a high arctic glacier: Midre Lovénbreen, Svalbard. (MSc thesis, University of Bochum.)

Brock, B.W. and N.S. Arnold. 2000. A spreadsheet-based point surface energy balance model for glacier and snowmelt studies. Earth Surf. Proc. Land., 25(6), 649-658.

Førland, E.J. and I. Hanssen-Bauer. 2003. Past and future climate variations in the Norweigan arctic: overview and novel analysis. Polar Res., 22(2), 113-124.

Hagen, J.O., J. Kohler, K. Melvold and J.-G. Winther. 2003. Glaciers in Svalbard: mass balance, runoff and freshwater flux. Polar Res. 22(2), 145-159.

Hodson, A.J., A.M. Gurnell, R. Washington, M. Tranter, M.J. Clark and J.O. Hagen. 1998. Meteorological and runoff time-series characteristics in a small, high-Arctic glaciated basin, Svalbard. Hydrol. Process., 12(3), 509-526.

Hodson, A.J., M. Tranter, and G. Vatne. 2000. Contemporary rates of chemical denudation and atmospheric $\mathrm{CO}_{2}$ sequestration in glacier basins: an Arctic perspective. Earth Surf. Proc. Land., 25(13), 1447-1471.

Hodson, A.J., P.N. Mumford, J. Kohler and P.M. Wynn. 2005. The High Arctic glacial ecosystem: new insights from nutrient budgets. Biogeochemistry, 72(2), 233-256.

Hop, H. and 27 others. 2002. The marine ecosystem of Kongsfjorden, Svalbard. Polar Res., 21(1), 167-208.

Jansson, P. 1999. Effect of uncertainties in measured variables on the calculated mass balance of Storglaciären. Geogr. Ann., 81A(4), 633-642.

Jansson, P., R. Hock and T. Schneider. 2003. The concept of glacier storage: a review. J. Hydrol., 282(1-4), 116-129.

Killingtveit, ̊., L.E. Pettersson and K. Sand. 2003. Water balance investigations in Svalbard. Polar Res., 22, 161-174.

Kulessa, B. and T. Murray. 2003. Slug-test derived differences in bed hydraulic properties between a surge-type and non-surge-type Svalbard glacier. Ann. Glaciol., 36, 103-109.

Rippin, D. and 6 others. 2003. Changes in geometry and subglacial drainage of Midre Lovénbreen, Svalbard, determined from digital elevation models. Earth Surf. Proc. Land., 28(3), 273-298.

Rippin, D.M., I.C. Willis, N.S. Arnold, A.J. Hodson and M. Brinkhaus. 2005. Spatial and temporal variations in surface velocity and basal drag across the tongue of the polythermal glacier midre Lovénbreen, Svalbard. J. Glaciol., 51(175), 588-600.

Willis, I., N. Arnold and B. Brock. 2002. Effect of snowpack removal on energy balance, melt and runoff in a small supraglacial catchment. Hydrol. Process., 16(14), 2721-2749. 